\title{
Risk Management Application at Performance Based Contracts Based on Project Life Cycle Using AHP Method (Case Study at Road Maintenance Project in Indonesia)
}

\author{
Asri Nurdiana ${ }^{1, *}$ and Mochammad Agung Wibowo ${ }^{2}$ \\ ${ }^{1}$ Department of Civil Engineering, School of Vocation, Diponegoro University, Semarang 50275, Indonesia \\ ${ }^{2}$ Department of Civil Engineering, Faculty of Engineering, Diponegoro University, Semarang 50275, Indonesia \\ Performance Based Contract is the innovation in contracts at construction, that the payment system is based on \\ contractor performance. In this contract, there are risks from both the contractor's and owner's perception. The \\ aims of this study are to identify and analyze the risk from contractor's and owner's perception at Performance \\ Based Contracts based on project life cycle. Primary data were taken through the questionnaire and interview, \\ then processed using AHP (Analytical Hierarchy Process) method. The secondary data are the data in project \\ and literature from previous studies. The identification of risks are reviewed by the project life cycle, and it is \\ known that the risks of contractor's and owner's perception are different.
}

Keywords: Risk Management at Construction, Performance Based Contracts, Project Life Cycle.

\section{INTRODUCTION}

Contract at construction project in Indonesia that used by government is less effective. Because this contract is restricted to one year budget of government, and the construction only has 4-8 months to complete. This problem can influence to quality of the project. Based on this background, the government tries to use another type of contract that can increase the quality of project. Performance Based Contracts is a type of contract that has 4 years to complete. It consists of 540 days to construction phase, 460 days to phase of life service maintenance, and 360 days of maintenance phase.

A performance-based contract (PBC) differs significantly from a method-based contract that has been traditionally used to maintain roads. In PBC, payments for the management and maintenance of road assets are explicitly linked to the contractor successfully meeting or exceeding certain clearly defined minimum performance indicators. ${ }^{8}$

At project there are risks, and also at Performance Based Contract project. The difference in the type of contract will bring the difference in risk in it. Usually, the contract terms often do not clearly indicate which party is to be regarded as bearing a risk. $^{1}$ Risk is a consequent from the uncertainty. At construction project, the uncertainty is vary. It can be conclude that in

${ }^{*}$ Author to whom correspondence should be addressed. construction project, stakeholders must manage the risk, so that risk can be reduce the probability and the impact of risk if that risk happened. ${ }^{2}$ Project specific risk is an important factor when appraising capital projects, for to ignore it can result in highrisk projects being accepted with catastrophic consequences. ${ }^{3}$ Risk management consist of Risk Identification, Risk Analysis, Risk Response, Risk Monitoring and Control. ${ }^{4}$

Risks are borned by each stakeholder in the project, such as contractor, owner, consultant of planning, supervisory consultant, and society around the area of the project. ${ }^{2}$ This various parties will carry the different risks because of their differences in the interest of the project. There are several significant differences from the the comparison between the owners and contractors' perceptions of risks in Indonesian construction projects. 5 Contractor and owner had the different expectations toward the allocation of a number of risks, and at present, many risks are unclearly apportioned to the contracting parties. The perception of risk varies at both individual and organisational levels because different people hold different views and have different understandings of a particular risk's components, sources, probabilities, consequences and preferred actions. ${ }^{6}$ People's beliefs, attitudes, judgments and feelings are believed to influence risk perception to a certain extent. ${ }^{7}$

Risk at construction project not only identified from construction phase. This risk must be identified from the others phase in project life cycle. Project life cycle are feasibility study, planning 
Table I. Risk level from constractor's perception that is analyzed with analytical hierarchy process method.

\begin{tabular}{|c|c|c|c|c|c|c|c|}
\hline Project life cycle & Weight & Code & Risk identification & Probability & Impact & Risk level & Risk rank \\
\hline \multirow[t]{2}{*}{ Recovery phase } & \multirow[t]{2}{*}{0.150} & $\mathrm{~A} 1$ & Wrong estimation for quantity & 0.075 & 0.075 & 0.005625 & 5 \\
\hline & & A2 & The problem of the status of the road & 0.075 & 0.075 & 0.005625 & 6 \\
\hline \multirow[t]{5}{*}{ Construction phase } & \multirow[t]{5}{*}{0.150} & B1 & Improper design & 0.016 & 0.012 & 0.000185 & 12 \\
\hline & & B2 & Problem of cashflow & 0.019 & 0.022 & 0.000411 & 11 \\
\hline & & B3 & Traffic jam because the project & 0.075 & 0.077 & 0.005748 & 4 \\
\hline & & B4 & Society disagree with the project & 0.006 & 0.006 & 0.000038 & 13 \\
\hline & & B5 & Cost of project rises & 0.035 & 0.033 & 0.001149 & 9 \\
\hline \multirow[t]{4}{*}{ Life service maintenance } & \multirow[t]{4}{*}{0.558} & $\mathrm{C} 1$ & Load of vehicle exaggerate & 0.309 & 0.305 & 0.094355 & 1 \\
\hline & & $\mathrm{C} 2$ & Roadside is functionalized exaggerate & 0.157 & 0.152 & 0.023886 & 2 \\
\hline & & $\mathrm{C} 3$ & Failed of the building & 0.028 & 0.069 & 0.001953 & 8 \\
\hline & & $\mathrm{C} 4$ & Changes in political policy & 0.064 & 0.032 & 0.002023 & 7 \\
\hline \multirow[t]{2}{*}{ Maintenance phase } & \multirow[t]{2}{*}{0.142} & D1 & Care insurance is scorched & 0.028 & 0.020 & 0.000565 & 10 \\
\hline & & D2 & $\begin{array}{l}\text { Penalties because road services are } \\
\text { not fulfilled }\end{array}$ & 0.114 & 0.122 & 0.013873 & 3 \\
\hline
\end{tabular}

and design, construction, turn over and start up. ${ }^{4}$ In Performance Based Contract, project life cycle consist of recovery phase, construction phase, phase of life service maintenance, and maintenance phase. The aims of this study are to identify and analyze the risk from contractor's and owner's perception at Performance Based Contracts based on project life cycle.

\section{MATERIALS AND METHODS}

Primary data were taken through the questionnaire and interview, then processed using AHP (Analytical Hierarchy Process) method. Analytical Hierarchy Process is one of some methods in Decision Support Systems that developed by Thomas L. Saaty. ${ }^{9}$ The survey was designed to get the priority of risk at Performance Based Contract project. Respondent were asked to identify the risk and give weight the risk. Respondents were the decission maker from contractor and owner on PBC project in Indonesia. The survey was conducted in 2014-2015. The secondary data are the data in project and literature from previous studies. This case study has been done on road maintenance project with Performance Based Contract.
After obtained the identification of risk and the weight of risk, analysis then performed using the AHP method. This analysis was done by pairwise comparison that comparing the level of impact and probability of risk. The value of impact and probability were multiplied to get the risk level. After the risk level was obtained, the risk rank will be known by prioritize the value of risk level. At the final step, descriptive analysis was used to get the description of risk in PBC project from contractor's and owner's perception.

\section{RESULTS AND DISCUSSION}

In this studies, risk was identified from contractor's and owner's perception at Performance Based Contracts project. This risk was identified from project life cycle. However, project life cycle at Performance Based Contracts project are recovery phase, construction phase, phase of life service maintenance, and maintenance phase. The identification of risk is created in a hierarchical structure.

After identify the risk, risk analysis was done by giving weight to the probability and impact of risk from contractor's perception

Table II. Risk level from owner's perception that is analyzed with analytical hierarchy process method.

\begin{tabular}{|c|c|c|c|c|c|c|c|}
\hline Project life cycle & Weight & Code & Risk identification & Probability & Impact & Risk level & Risk rank \\
\hline \multirow[t]{3}{*}{ Recovery phase } & 0.150 & E1 & Improper study (feasibility study) & 0.010 & 0.010 & 0.000099 & 12 \\
\hline & & E2 & $\begin{array}{l}\text { The quality of contractor and } \\
\text { supervisory consultant are not as } \\
\text { expected }\end{array}$ & 0.014 & 0.046 & 0.000627 & 10 \\
\hline & & E3 & $\begin{array}{l}\text { Personnel and services from } \\
\text { contractor are not as the quotes } \\
\text { from contractor }\end{array}$ & 0.049 & 0.076 & 0.003700 & 5 \\
\hline \multirow[t]{5}{*}{ Construction phase } & 0.150 & $\mathrm{~F} 1$ & $\begin{array}{l}\text { The quality of material is not } \\
\text { according to specifications }\end{array}$ & 0.026 & 0.058 & 0.001521 & 7 \\
\hline & & $\mathrm{F} 2$ & $\begin{array}{l}\text { Contractor claim for change order is } \\
\text { above the contract }\end{array}$ & 0.019 & 0.079 & 0.001478 & 8 \\
\hline & & F3 & $\begin{array}{l}\text { Design is not appropriate with the } \\
\text { project }\end{array}$ & 0.060 & 0.094 & 0.005597 & 4 \\
\hline & & $\mathrm{F} 4$ & Wrong estimation for owner estimate & 0.064 & 0.183 & 0.011646 & 3 \\
\hline & & F5 & Increasing of project cost & 0.014 & 0.060 & 0.000845 & 9 \\
\hline \multirow[t]{2}{*}{ Life service maintenance } & 0.558 & G1 & Road service levels are not fulfilled & 0.390 & 0.257 & 0.100173 & 1 \\
\hline & & G2 & $\begin{array}{l}\text { The changes of contractor's } \\
\text { performance because there are } \\
\text { changes in political policy }\end{array}$ & 0.058 & 0.035 & 0.002018 & 6 \\
\hline \multirow[t]{2}{*}{ Maintenance phase } & 0.142 & $\mathrm{H} 1$ & $\begin{array}{l}\text { Contractor is not responsible to the } \\
\text { failed of building }\end{array}$ & 0.268 & 0.089 & 0.023777 & 2 \\
\hline & & $\mathrm{H} 2$ & Care insurance can't be scorched & 0.040 & 0.012 & 0.000479 & 11 \\
\hline
\end{tabular}


using AHP method for each level of the hierarchy. The results of risk analysis from contractor's perception are shown at Table I. Risk level from owner's perception is shown at Table II.

Tables I and II show the risk level and risk rank from identified risk. From risk analysis we can conclude that there is different perception from different stakeholders. But, both of contractor's and owner's perception, the most important risk is that risk in phase of life service maintenance.

At this case study, the comprehensive risk from contractor's and owner's perception are: the primary risk is risk at phase of life service maintenance (74\%), the second risk is risk at the maintenance phase (12\%), the third risk is risk at the construction phase $(9 \%)$, then the fourth risk is risk at recovery phase (5\%).

From contractor's perception, risk that is classified by project life cycle in Performance Based Contract project are $79 \%$ at phase of life service maintenance, $9 \%$ at maintenance phase, $7 \%$ risk at recovery phase, and 5\% risk at construction phase. However, from owner's perception, risk that is classified by project life cycle in Performance Based Contract project are $67 \%$ at phase of life service maintenance, $16 \%$ at maintenance phase, $14 \%$ risk at construction phase, and 3\% risk at recovery phase. It can be conclude that in Performance Based Contract, the most risk is at phase of life service maintenance both of contractor's perception and owner's perception.

There is a different scheme between risk at Performance Based Contract project and risk at traditional type of contact at project. In Performance Based Contract project, the most risk is in at phase of life service maintenance. Whereas in the traditional type of contact at project, the most risk is in the construction stage. ${ }^{10}$

\section{CONCLUSION}

The identification of risks are reviewed by the project life cycle, and it is known that the risks of contractor's and owner's perception are different. These risks are the risk at recovery phase, construction phase, phase of life service maintenance, and maintenance phase. The risk from contractor's and owner's perception, the most important risk is that risk in phase of life service maintenance.

\section{References and Notes}

1. M. Loosemore and C. S. McCarthy, Journal of Professional Issues in Engineering Education and Practice 134, 95 (2008).

2. A. Nurdiana, M. A. Wibowo, and J. U. D. Hatmoko, Procedia Engineering 125, 12 (2015).

3. J. Hynek, V. Janeček, F. Lefley, and K. Půžová, International Journal of Systems, Control and Communications (IJSCC) 6 (2014).

4. Project Management Institute, Project Management Institute, Inc. (2004).

5. Andi, Construction Management and Economics 24, 69 (2006).

6. M. Loosemore, J. Raftery, C. Reilly, and D. Higgon, 2nd edn., Taylor and Francis, Oxon, UK (2006).

7. A. S. Akintoye and M. J. Macleod, International Journal of Project Management 15, 31 (1997)

8. R. Wirahadikusumaha, B. Susantia, V. Coffeyb, and C. Adighibeb, Procedia Engineering (2015).

9. T. L. Saaty, McGraw-Hill, New York (1980).

10. C. S. Goh and H. Abdul-Rahman, Journal of Construction in Developing Countries 18, 19 (2013). 